\title{
RELIGIOUS FREEDOM AND THE AUSTRALIAN CONSTITUTION - ORIGINS AND FUTURE
}

\author{
Luke Beck (Routledge 2018) pp 178 \\ Jocelynne A. Scutt*
}

The most recent Australian Census, conducted by the Australian Bureau of Statistics (ABS) in 2016 (with a 95.1 per cent response rate), confirms that Australia is 'increasingly a story of religious diversity, with Hinduism, Sikhism, Islam, and Buddhism all increasingly common religious beliefs'. ${ }^{1}$ Of these, between 2006 and 2016 Hinduism shows the 'most significant growth', attributed to immigration from South East Asia, whilst Islam (2.6 per cent of the population) and Buddhism (2.4 per cent) were the most common religions reported next to Christianity, the latter 'remaining the most common religion' (52 per cent stating this as their belief). Nevertheless, Christianity is declining, dropping from 88 per cent in 1966 to 74 per cent in 1991, and thence to the 2016 figure. At the same time, nearly one-third of Australians (30 per cent) state they have no religion, ${ }^{2}$ this group reflecting 'a trend for decades' which, says the $\mathrm{ABS}$, is 'accelerating':

Those reporting no religion increased noticeably from 19\% in 2006 to $30 \%$ in 2016 [with] the largest change ... between 2011 (22\%) and 2016, when an additional 2.2 million people reported having no religion. ${ }^{3}$

In this, there were not insignificant differences between the states: Tasmania reported the lowest religious affiliation rate (53 per cent), whilst New South Wales had the highest rate (66 per cent). Age was a significant factor, both in terms of particular religious affiliation and in the 'no religion' category. Those aged sixtyfive years or more were more likely to profess an adherence to Christianity. Young adults aged between eighteen and thirty-four years had a greater likelihood of

Senior Teaching Fellow, University of Buckingham.

1 '2016 Census Data Reveals 'No Religion' is Rising Fast' (Australian Bureau of Statistics) <http://www.abs.gov.au/AUSSTATS/abs@.nsf/mediareleasesbyReleaseDate/ 7E65A144540551D7CA258148000E2B85> accessed 10 October 2018.

2 Ibid.

3 Ibid. 


\section{BOOK REVIEWS}

affiliation with religions other than Christianity (12 per cent) or to state they had 'no religion' (39 per cent). ${ }^{4}$

Yet just as in the United States, despite 'separation of church and state', the George W Bush administration (2001-09) promoted a strongly religious approach, ${ }^{5}$ and in the United Kingdom Tony Blair when Prime Minister (1997-2007) had religion as a guide, ${ }^{6}$ in Australia Prime Minister John Howard (1996-2007) followed suit. ${ }^{7}$ The emphasis upon religion - that is, Christianity - was in the Australia context straying into territory generally seen as 'foreign' to government. ${ }^{8}$ This was more so, in light of the increasing numbers professing no religion. Against this backdrop, the publication of Luke Beck's Religious Freedom and the Australian Constitution - Origins and Future is opportune.

The book begins with the tale of a bricklayer, setting the scene for an historical account of the impact one religion in particular, Seventh Day Adventism, had upon efforts taken to ensure that the Australian Constitution would incorporate a 'religious freedom' condition. Beck recounts how Constable Thomas Burke of the Sydney police confronted Robert Shannon who was engaged in building a brick and cement house in inner-Sydney's Albion Street, Leichhardt. The day was Sunday, Shannon was a Seventh Day Adventist, and the Sunday Observance Act 1677 was operative in New South Wales. This made it unlawful for any 'Tradesman, Artifice Workeman Labourer or other Person whatsoever' to 'do or exercise any worldly Labour, Busines or Worke of their ordinary Callings upon the Lords day or any part thereof (Workes of Necessity only excepted)'. ${ }^{9}$ Shannon's protest that

4 Ibid.

5 See George W Bush, Decision Points (Crown Publishing Group 2001) providing an insight into his religious commitment.

${ }^{6}$ His autobiography covering his political career confirms the religious underpinnings of his life and work. See Tony Blair, A Journey - My Political Life (Random House 2010).

7 John Howard, Lazarus Rising - A Personal and Political Biography (HarperCollins 2010) attests to his religious beliefs as important to his standing.

${ }^{8}$ Renae Barker, 'Is Australia a Secular Country? It Depends What You Mean' (The Conversation) $<$ https://theconversation.com/is-australia-a-secular-country-it-depends-whatyou-mean-38222> accessed 7 November 2018; Amy Chien-Yu Wang, 'Freedom of Religion and Secularism in Australia' (SBS Radio - Settlement Guide, 27 October 2017) $<$ https://www.sbs.com.au/radio/audiotrack/freedom-religion-and-secularism-australia > accessed 5 November 2018; Graham Innes, 'Are We Really the Secular Nation We Think We Are?' (Australian Human Rights Commission, 20 November 2009) <https://www. humanrights.gov.au/news/opinions/are-we-really-secular-nation-we-think-we-are-2009> accessed 5 November 2018.

9 Quoted by Luke Beck, Religious Freedom and the Australian Constitution,1 (hereafter 'Beck'). 
for him 'the Lords day' or 'Sabbath' was not Sunday, but Saturday, was to no avail. On 9 August 1894 Shannon appeared at Glebe Police Court where he and Burke gave evidence of their encounter. Then followed arguments incorporating theology, a proclamation made by Victoria in 1858, and a request for an adjournment, all presented articulately by Shannon. Yet despite his submissions, Shannon stood convicted and 'fined 2 shillings 6 pence and costs, or in default to be set publicly in the stocks for two hours'. ${ }^{10}$ Opting for the stocks proved to be his saving. Stocks being unavailable, the proposition that they should be built especially for Shannon and that he would be displayed publicly in the streets created such furore - going beyond Sydney to Melbourne and engaging the oratorical attention of a United States identity - that upon the government's advice, the Governor remitted the sentence. ${ }^{11}$

This prosecution and others before it propelled the Seventh Day Adventist Church into action, ensuring their continuing attention to proposals for fashioning a federation out of the Australian colonies. Their influence in the Constitutional Convention debates is recounted by Beck, who observes that Henry Bournes Higgins, a principal player in the formulation of the Constitution, was largely motivated by the desire to ensure that this religious group along with others could support federation. ${ }^{12}$

Section 116 of the Australian Constitution, the provision known by the shorthand term 'religious freedom', provides:

The Commonwealth shall not make any law for establishing any religion, or for imposing any religious observance, or for prohibiting the free exercise of any religion, and no religious test shall be required as a qualification for any office or public trust under the Commonwealth.

In 12 chapters, Religious Freedom and the Australian Constitution recounts the history of section 116, what motivated its wording and constitutional inclusion, its relation to the Constitution's preamble and what its terms actually mean - or may mean, efforts to amend it during the Conventions and in the following century, its interpretation by the High Court, and its future.

Readers may be surprised to learn that section 116 began its life as a provision not relating to the powers of the Commonwealth, but to those of the states. The states' provision preceded the formulation of the Commonwealth provision then, when Andrew Inglis Clerk, Attorney General for Tasmania, prepared a draft

${ }^{10}$ Beck (n 9) 2.

${ }^{11}$ Beck (n 9) 2-3.

12 Beck (n 9) 103-04. 


\section{BOOK REVIEWS}

Constitution Bill to provide the basis for discussion at the 1891 Convention, both states ('provinces' in the draft) and Commonwealth were covered by stipulations relating to religion: ${ }^{13}$

46. The Federal Parliament shall not make any Law for the establishment or support of any religion, or for the purpose of giving any preferential recognition to any religion, or for prohibiting the free exercise of any religion.

81. No Province shall make any law prohibiting the free exercise of any religion.

Ultimately, the impetus for requiring the states to refrain from controls over or interference with religious observance or religion itself was lost, so that the Commonwealth alone wears any constitutional constraints covering religion. Yet, as Beck points out, there is no universal agreement as to what section 116 in all its terms actually means. Religious Freedom and the Australian Constitution outlines the very different positions taken by Justices Ninian Stephen and Lionel Murphy in the 1981 High Court decision Attorney-General (Vic); Ex Rel Black $v$ Commonwealth. ${ }^{14}$ The majority decided that federal funding of religious schools did not violate the establishment clause of section 116, Stephen (in the majority) calling upon English jurisprudence in support, Murphy (in dissent) asserting that the provision was framed not with regard to the United Kingdom, but to the United States. Although concluding that neither Stephen nor Murphy was correct in stipulating one or the other as the origin, Beck nonetheless concedes ${ }^{15}$ the logic of Murphy's view in that the First Amendment of the US Constitution provides that Congress 'shall make no law respecting an establishment of religion, or prohibiting the free exercise thereof...' Additionally, article IV states: '...no religious Test shall ever be required as a Qualification to any Office or public Trust under the United States'.

As it is, Beck considers that the 'starting point' of any determination as to the meaning of section 116 should be the history of the provision in its Australian context - beginning with the Constitutional Conventions. The starting point should not lie with the United Kingdom as a whole, nor with England, nor with the United States. Accordingly he thoroughly relates the Australian history through eight of his twelve chapters: chapter 1, 'A sabbath breaker in the stocks', chapter 2, 'Arguing for a religious character to the Australian Constitution',

13 Beck (n 9) 79.

14 [1981] HCA 2, 146 CLR 559.

15 Ibid 5. 
chapter 3, 'Arguing against a religious character to the Australian Constitution', chapter 4, 'A constitutional recognition of God', chapter 5, 'A constitutional prohibition against religious laws', chapter 6, 'The argument for section 116', chapter 7, 'The language of section 116', and chapter 8, 'The original understanding of section 116'. All are well-worth reading, bringing to life as they do the constitutional debates, the delegates, the drafts, the characters, the personalities and the arguments.

For those with a passion for philosophy, chapter 9 will be of particular notice, traversing as it does 'What is the point of section 116' by reference to 'The neutrality theory', 'The safeguard against religious intolerance theory', 'Comparing the two theories', 'Why the neutrality theory is wrong' and 'Why the safeguard against intolerance theory is right'. For the parliamentary draftsperson and all possessing a passion for legislative drafting and statutory interpretation, chapter 8 , 'The original understanding of section 116' will be of some interest. Beck explores the meaning and understanding of the word 'for', along with 'establishment', 'religious observance', 'free exercise' and 'religious tests'. Necessarily, it may be said, he makes reference also to 'American jurisprudence', ending the chapter with the conclusion that the Federal Convention 'was not concerned with precise meanings', at least insofar as the 'religion' provision was concerned. ${ }^{16}$ Ultimately he observes, 'the precise language' of section 116 'did not receive close attention by the Convention', ${ }^{17}$ and perhaps thereby its language 'is rather haphazard'. ${ }^{18}$ As it proved, the provision went through without demur, although (or perhaps because) many present thought it unnecessary as they considered the federal Parliament had no power in relation to religion in any event. ${ }^{19}$

Again perhaps because of this inattention to the language, the 1940s and the second half of the $20^{\text {th }}$ Century saw efforts to amend section 116 . These gave rise to referenda addressing its scope. In Chapter 10, 'HV Evatt's attempts to amend section 116 in the 1940s', Beck recounts the history of the 1940s push, the brainchild of Dr H V Evatt who served in the New South Wales lower house - the Legislative Assembly (1925-30) then was appointed to the High Court in 1930, serving until 1940 when he retired to stand for the Federal Parliament. There, he was Attorney General in a Labor Government (1941-49) and eventually leader of the Labor Opposition (1951-60), then Chief Justice of the Supreme Court of New South Wales (1960-62). He proposed a new section 60A incorporating, amongst other matters, four freedoms - freedom of speech and expression, religious

\footnotetext{
16 Ex Rel Black (n 14) 98-129.

17 Ex Rel Black (n 14) 96.

18 Ex Rel Black (n 14) 97.

19 Ex Rel Black (n 17).
} 


\section{BOOK REVIEWS}

freedom, freedom from want, and freedom from fear. His proposition was that whilst section 116 operated simply as a 'shield' against encroachments on religious freedom, the new provision would re-orientate the constitutional profile with section 60A providing 'a sword wielded by the Commonwealth to bring about religious freedom in practice'. ${ }^{20}$ The aim was to ensure constitutional recognition of 'the great ends of economic security, social justice and individual freedom'. It faltered, however, when the Referendum Bill failed to proceed beyond first reading in the House of Representatives. ${ }^{21}$

Evatt was not defeated. As Beck points out, the government then convened a Constitutional Convention including from the House of Representatives Evatt and three of his colleagues, plus four opposition members, and four from the Senate, together with each state's Premier and Leader of the Opposition. Evatt composed a short volume as a basis for Convention discussion, which included a paragraph seeking to define religious freedom as it appeared in his original Bill:

Freedom of religion - means (a) freedom of conscience and the free profession and practice of religion are, subject to public order and morality, guaranteed to every citizen; (b) that no person shall be subject to any disability or be required to take any oath on account of his religion or religious belief, and no religious test shall be imposed in respect of the appointment to or holding of any public office; (c) that no law shall be made for establishing any religion or for imposing any religious observance or for prohibiting the free exercise of any religion. ${ }^{22}$

Analysing the paragraph and observing that this is 'not really' a definition, Beck notes that in the end Evatt sought simply to rework the existing section 116. The Convention concluded without advancing the 'freedom of religion' question further, with the 'only significant comment' being that 'constitutional guarantees of religious freedom [are] unnecessary in Australia'. ${ }^{23}$

In 1944 Evatt tried again with another Bill to amend the Constitution. This included amongst other 'safeguards' one which sought to apply the prohibitions of section 116 to the states. ${ }^{24}$ This took the matter back to the original $1890 \mathrm{~s}$

20 Ex Rel Black (n 14) 132.

21 Ex Rel Black (n 14) 133.

${ }^{22}$ H V Evatt, Post-war Reconstruction: A Case for Greater Commonwealth Powers (Commonwealth Government Printer 1942) 11; cited by Beck (n 9) 134.

23 Beck (n 9) 137 (quoting Robert Menzies - who had served as Prime Minister (193941), though then a backbencher).

24 Ibid. 
Constitutional Convention position. The proposal foundered along with all the other provisions when the referendum, held on 19 August 1944, was lost, failing to obtain the required national majority and gaining majorities in two states only, Western Australia and South Australia. ${ }^{25}$ Beck recounts the parliamentary and public debates surrounding the referendum, contrasting Evatt's approach with that of Robert Menzies, later to become leader of the Liberal Party of Australia and Prime Minister (1949-66). Beck provides an insightful consideration of Evatt's reliance on US jurisprudence, as against Menzies' competing scepticism about what today would be called 'the human rights project'. ${ }^{26}$

Chapter 11, 'Post-war attempts to amend section 116' covers the ground from 1973 to 1988, 'The Australian Constitutional Convention of 1973-85', 'Whitlam's attempt to extend section 116 to the States', 'The Constitutional Commission of 1985-88' and 'The 1988 rights and freedoms referendum'. Beck observes that the 1981 'DOGS' case - 'Defence of Government Schools' - which sought to ensure that public funding was directed to the secular government education system, and not to schools founded upon religions, ${ }^{27}$ gave an added impetus to attempts to clarify or amend section $116 .{ }^{28}$ He quotes the replacement provision proposed by The Movement for the Defence of Government Schools:

116. A State shall not, nor shall the Commonwealth, make any law for establishing any religion, or for imposing any religious observance, or for prohibiting the free exercise of any religion, and no religious test shall be required as a qualification for any office or public trust under a State or under the Commonwealth. ${ }^{29}$

Other submissions to the Constitutional Convention similarly advocated extending section 116 to the states. However, this effort, as Evatt's before it, failed. So did the other attempts of the 1970s and 1980s, all notably driven by Labor Governments. $^{30}$

25 H V Evatt cited by Beck (n 22) 139-40.

${ }^{26} \mathrm{H}$ V Evatt cited by Beck (n 22) 139-42.

27 Attorney-General (Vic), Ex Rel Black v Commonwealth ('DOGS' case') [1981] 146 CLR 559.

28 Ibid, 143-44.

29 DOGS case (n 27) 144.

30 DOGS case (n 27) 145-48 (Whitlam Labour government), 148-55 (Hawke Labour government). 


\section{BOOK REVIEWS}

Beck's concluding chapter 12, 'The future of section 116' provides an astute discussion under headings 'How does section 116 provide a safeguard against religious intolerance?', 'Section 116 is concerned with the practical operation of laws', 'Section 116 should not be interpreted narrowly', 'Section 116 should be interpreted to avoid religious intolerance on the part of the Commonwealth', and 'The future of section 116'. Liberal Prime Minister John Howard's introduction of the 'school chaplaincy programme' provides a good basis for Beck's wrapping up discussion. In 2007, this programme was introduced under Guidelines describing it as 'a voluntary Programme that will assist schools and their communities to support the spiritual well-being of their students' ${ }^{31}$ The Commonwealth granted funding under contracts with organisations providing chaplains to schools. This generated concern within that part of the Australian community holding that the provision of such services is to support religion within the school sector and breach section 116. Williams v Commonwealth ('the Schools Chaplains Case') was run on the basis that the programme guidelines 'implemented a religious test for a public office or trust under the Commonwealth'. Beck provides a short analysis of the judgment and reasoning, the High Court upholding the programme on the basis not that there was no religious test involved, but that 'the position of a school chaplain was not "under the Commonwealth". ${ }^{32}$ The Commonwealth made payments 'only ... once it had received programmes reports about the provision of chaplaincy services', and 'could also directly monitor the work of chaplains by conducting visits to schools and by seeking feedback about their work' ${ }^{33}$ The High Court concluded that the chaplains 'held no office under the Commonwealth'. ${ }^{4}$ 'Under', they said, 'indicates a requirement for a closer connection to the Commonwealth than that presented by the facts of this case'. ${ }^{35}$ There was, therefore, no breach of section 116. Beck disagrees, concluding that this determination runs counter to an interpretation of section 116 as designed to 'avoid religious intolerance on the part of the Commonwealth'. Surely 'religious intolerance' is, runs Becks argument, that at which the provision aims. He contends that had the High Court considered this as the guiding light for section

31 DOGS case (n 27) 164 (citing Department of Education, Science and Training (Cth), National School Chaplaincy Programme Guidelines 19 January 2007).

32 Ibid.

33 Ibid.

34 DOGS case (n 27) 165 (quoting Justice Gummow and Justice Bell, Chief Justice French and Justices Hayne, Crennan and Kiefel concurring in Williams $v$ Commonwealth [2012] 248 CLR 156, [109]-[110]).

35 Ibid. 
116 (which, he proposes, it ought), 'the High Court's decision ... is likely to have been different'. ${ }^{36}$

In the upshot, the plaintiff in Williams $v$ Commonwealth, Ron Williams - an atheist whose children attended a school which employed a chaplain, won because the High Court held that the Commonwealth could not fund the programme without legislation passed by the federal Parliament. Ultimately, however, Williams lost for (on top of the restrictive and restricting interpretation of section 116) legislation was duly passed and the programme continued, despite considerable objection. ${ }^{37}$ However, it does not continue unchallenged, most recently by a chaplain claiming discrimination on religious grounds as, although employed by three schools, she was refused employment in primary schools on the ground of her not being a Christian. ${ }^{38}$ In the Victorian Civil and Administrative Tribunal (VCAT), the claimant's argument was reported as finding support in Williams and Justice Heydon's view that the work to be undertaken by 'chaplains' 'could have been done by persons who met a religious test [and] could equally have been done by persons who did not'. ${ }^{39}$ Unfortunately, Beck's book went to press before the VCAT case was launched, and the VCAT proceeding had reached

36 Ibid.

37 Theophilus, 'So What's the Problem with Government-Funded Chaplains in State Schools?' (The Conversation, 19 June 2014), <http://theconversation.com/so-whats-theproblem-with-government-funded-chaplains-in-state-schools-28211> accessed 19 November 2018; Paul Karp, 'Secular Groups Call for Review of "Blatantly Discriminatory" Schools Chaplaincy Program' The Guardian (1 April 2018) < https://www.theguardian. com/australia-news/2018/apr/01/secular-groups-call-for-review-of-blatantlydiscriminatory-school-chaplains-program> accessed 19 November 2018; Paul Karp, 'School Chaplains: Secular Groups Say Review is Proof of Religious Proselytising' The Guardian(31 May2018)<https://www.theguardian.com/australia-news/2018/jun/01/schoolchaplains-secular-groups-say-review-is-proof-of-proselytising $>$ accessed 19 November 2018; Paul Karp, 'School Chaplains Agency Faces Tax Challenge over \$33m in Donations' $<$ https://www.theguardian.com/world/2018/sep/23/school-chaplains-agency-faces-taxchallenge-over-33m-in-donations $>$ accessed 19 November 2018.

38 Amy Remeikis, 'School Chaplains Legal Challenge Argues Program is Discriminatory' The Guardian (13 June 2018) <https://www.theguardian.com/australia-news/2018/jun/14/ school-chaplains-legal-challenge-argues-program-is-discriminatory $>$ accessed 19 November 2018.

39 Ibid; see also Damien Hurst, 'Budget: It Will Be Chaplains, Not Social Secular Workers, in Schools' (14 May 2014) <https:/www.theguardian.com/world/2014/may/14/ budget-it-will-be-chaplains-not-secular-social-workers-at-schools $>$ accessed 19 November 2018. 


\section{BOOK REVIEWS}

compulsory conference stage only by December $2018,{ }^{40}$ so Religious Freedom and the Australian Constitution does not include reference to it. The book was completed, too, before the Turnbull government launched its 'review into religious freedom'. Conducted by a former Liberal Party MP, Philip Ruddock, this caused further consternation on the part of those opposed to religion being intertwined with government. The impetus appeared to come from those within government opposed to gay marriage (the right to which had been won resoundingly in a plebiscite) and to equal opportunity and discrimination legislation which made religious discrimination unlawful. ${ }^{41}$

Still, Beck ends Religious Freedom and the Australian Constitution on a note that the 'separation of state and religion' lobby should find heartening. Albeit concluding that section 116 is 'unlikely to be amended to apply to the States [as] every attempt at doing so has failed, the most recent ... suffering the worst defeat of any referendum in Australian history', Beck sees section 116 as 'not ... without future prospects'. ${ }^{42}$ The High Court, he says, 'has seriously misunderstood the point' of section 116, and its 'reasoning ... is seriously flawed' in section 116 cases. ${ }^{43}$ He ends the book with the words:

Section 116 has the potential to provide a pragmatic safeguard against religious intolerance on the part of the Commonwealth, if only the High Court understood its history. ${ }^{44}$

This is on the one hand a strong claim. On the other, for those who have had an abiding interest in section 116 and its place in the Constitution as one of the few human rights provisions contained in it, Beck's book provides a welcome contribution. Beck avers that his book 'provides the history' crucial to future High Court decision-making. All who hope for a more reflective jurisprudential analysis

40 Advice from Associate Professor Beck, who acts for the claimant at VCAT: e-mail advice, 27 November 2018.

${ }^{41}$ Paul Karp, 'Philip Ruddock's Religious Freedom Review Holding Secret Hearings' The Guardian (7 February 2018) <https://www.theguardian.com/australia-news/2018/ feb/08/philip-ruddocks-religious-freedom-review-holding-secret-hearings $>$ accessed 19 November 2018; Paul Karp, 'Ruddock Religious Freedom Review: What Is It and What Do We Know So Far' The Guardian (October 11 2018) <https://www.theguardia.com/ australia-news/2018/oct/11/ruddock-religious-freedom-review-what-is-it-and-what-do-weknow-so-far> accessed 19 November 2018.

42 Ibid 165.

43 Ibid.

44 Ibid. 
of section 116 by the High Court, and who are interested in Australian constitutional law generally, will agree. Every High Court judge and those aspiring to the position should have the book on their bookshelves and, more, read it. For those without such aims, the book is one worthy of being not only on the shelf, but on the desk and well read. Religious Freedom and the Australian Constitution is an important addition to Australian constitutional law and scholarship, and will please the general reader, too. 